УДК 595.762

Коржова Т.А.: https://orcid.org/0000-0003-0547-2181

Маркіна Т.Ю.: https://orcid.org/0000-0002-6313-9814, Scopus Researcher ID56736553600

\title{
ОСОБЛИВОСТІ ЕКОЛОГІЧНОЇ СТРУКТУРИ ЖУКІВ-НЕКРОБІОНТІВ В ХАРКІВСЬКІЙ ОБЛАСТІ (УКРАЇНА)
}

\author{
(C) Коржова Т.А., Маркіна Т.Ю. \\ Харківський національний педагогічний університет імені Г. С. Сковороди, \\ tgtania1458@gmail.com; t.yu.markina@gmail.com \\ https://doi.org/10.34142/2708-5848.2020.22.2.08
}

Серед некробіонтної колеоптерофауни в Харківській області (Україна) зареєстровано 66 видів жуків 314 родин 3 яких 17 відзначені як домінанти або субдомінанти. До сапротрофної в широкому сенсі групи комах на трупах належить 23 види з 5-и родин (з них 10 видів звичайні): Dermestidae (9), Silphidae (8), Nitidulidae (5), Leiodidae (2) та Trogidae (один вид). Серед хижих ентомофагів виявлено 30 видів (з них сім звичайних) 3 трьох родин: Histeridae (15), Staphylinidae (12) та Cleridae (3 види). Серед представників випадкової групи, поодиноко зареєстровано 13 видів жуків з семи родин. Шкіроїд Attagenus brunneus зареєстровано як новий для фауни України, а карапузики Gnathoncus disjunctus suturifer, Saprinus planiusculus та S. rugifer вперше зазначені на території Лісостепу України. За біотопічним преферендумом домінували лісові (25) та політопні (23) види, з яких 15 віднесено до домінантів та субдомінантів. Лучний комплекс включав 12 видів, до степових віднесено чотири, а до синантропів - два види. За гігропреферендумом домінували мезофіли (45 видів, 3 них 13 звичайних). Мезогігрофіли представлені 10, а мезоксерофіли - 12 видами. За трофічною спеціалізацією на трупах таксономічно домінували зоофаги (30), менше - некросапрофаги (14), некрозоофаги (10 видів) та сапрофаги широкого спектру (8 видів). Проте, чисельно переважали некросапрофаги та некрозоофаги (з них 17 домінантних та субдомінантних видів). За мікростаціальною характеристикою виділено вісім груп, серед яких основними виявились стратонекробіонти (19), стратобіонти (16), стратокопронекробіонти (15 видів). Чисельно ці три групи значно переважали на трупах (всього відзначено 15 массових та звичайних видів), в порівнянні з іншими видами трупного колеоптерокомплексу. Серед стратокопробіонтів зареєстровано вісім видів. Інші мікростаціальні групи представлені стратоботробіонтами (3 види) та поодинокими стратогеобіонтами, стратохортобіонтами i дендробіонтами (по 1-2 видах кожна). Для кожної екологічної групи наведено дані щодо видового складу та чисельності.

Ключові слова: Coleoptera, некробіонти, біорізноманіття, видовий склад, чисельність, екологічні групи.

Однією з великих та важливих складових кожної наземної екосистеми $\epsilon$ твердокрилі комахи (Coleoptera), серед яких до фауністично цікавих та практично важливих відносяться жуки-некробіонти [6]. Вивчення представників цих груп в різноманітних ценозах має особливе значення як біоіндикаторів в криміналістиці, особливо в судовій ентомології [5, 14, 16, 22, 23, 25]. Не менш важливим $\epsilon$ дослідження жуківнекробіонтів в різноманітних оселищах 3 метою дослідження закономірностей формування їх фауни як складової тваринного населення в межах того чи іншого біотопу [7, $10,11,12]$.

Спеціальному вивченню жуків-некробіонтів в Східній Свропі присвячено небагато праць, більшість яких охоплюють окремі регіони Росії, наприклад північний захід [10, $12,15]$ та Ставропольський край [27-30]. В цих працях досить детально розглянуто таксономічну структуру та ряд екологічних характеристик некробіонтних видів твердокрилих в умовах того чи іншого регіону.

В Україні, роботи присвячені некробіонтним жукам, також нечисленні i проведені, головним чином в умовах сходу або містять дані по окремих родинах $[8,18$, $19,21,24,26,37]$. В цих статтях наведено фрагментарні дані видового складу та часових змін появи на трупах тварин різних видів комах. Оглядам окремих родин жуків, представлених переважно некробіонтами, також присвячена низка праць, але, головним чином, в умовах трансформованих ценозів [7, 31-36].

Загалом, в більшості наведених вище публікацій, питання екологічної структури жуків-некробіонтів розглянуто досить поверхнево.

Головна увага приділена особливостям сукцесійних змін колеоптерофауни на трупах, 
трофічній та стаціальній характеристикам основних видів, але менше їх біотопічному розподілу та гігропреферендуму в умовах окремих географічних зон України.

Метою нашої роботи було вивчення основних складових екологічної структури

\section{МАТЕРІАЛ ТА МЕТОДИКА}

Матеріалом даної роботи слугували збори жуків-некробіонтів, проведені першим автором на трупах тварин (котів та собак). Наші дослідження проводили влітку (збір комах проводився кожного дня ввечері з червня по серпень) в околицях м. Харкова в період 2009-2018 pp. Досліджено 4 ділянки в лісосмугах, в кожній по три повторності. Для дослідів використовували свіжі та непошкоджені трупи невеликих за розміром тварин вагою 5-7 кг. Збір комах та їх фіксацію проводили вручну або 3 використанням грунтових пасток у вигляді пластикових стаканів, залитих на чверть об’єму оцтовою кислотою. В кожній повторності використовували по три пастки, розміщених біля трупа тварини. Крім того, використовували i iнші загальноприйняті методики збору некробіонтних комах [16]. Матеріал фіксували в 70 \% спирті. Додатково для екологічного та фауністичного порівняльного аналізу використані дані зборів О.О. Прокопенко [24]. Обробку матеріалу проводили на кафедрі зоології ХНПУ імені Г.С. Сковороди та у Харківському НДІ судових експертиз ім. М.C. Бокаріуса в лабораторії судових хімічних, фізичних та біологічних досліджень.

Складові екологічної структури жуків надано для трьох основних комплексів: видів, типових для ентомофауни трупів, що безпосередньо приймають участь в утилізації мертвих тварин, тобто харчуються тканинами трупу, видів-ентомофагів, що живляться некробіонтними видами комах, що заселяють трупи та випадкових на трупах видів жуків. Наведений нижче огляд екологічної структури некробіонтної колеоптерофауни включає такі основні групи: біотопічна характеристика - за преференцією видів до певних біотопів; за відношенням до вологості (гігропреферендум), трофічна характеристика, на основі харчової спеціалізації видів, (чисельність, біотопічний та мікростаціальний розподіл, гігропреферендум, трофічна спеціалізація) жуків-некробіонтів, зареєстрованих на трупах тварин в умовах Східної України (Харківська область).

стаціальна належність - за рівнем місцеперебувань видів в окремих складових біотопу. Екологічна характеристика цих груп надана на основі власних спостережень та 3 використанням ряду літературних джерел присвячених вивченню різних родин жуків [9, 18, 20, 21, 32, 33, 37, 38, 40].

Всього, на трупах зібрано біля 500 екз. жуків. Виходячи 3 цієї величини вибірки, за рівнем чисельності виділено три групи. До масових (домінантів) віднесено види, частка яких перевищувала $15 \%$ загального числа жуків; до звичайних (субдомінантів) - від 1 до $14,9 \%$, нечисленних (рідкісних на трупах) менше $1 \%$. За бальною шкалою домінантам надано - 3, субдомінантам - 2, а рідкіснім - 1 бал. Основну увагу приділено першим двом групам як фоновим складовим некробіонтної колеоптерофауни, так як для багатьох рідкісних видів, інформація щодо екологічної характеристики практично відсутня. Для оцінки подібності видового складу жуківнекробіонтів на різних ділянках використовували коефіцієнт видової подібності Жаккара [7, 8].

Жуків визначали за допомогою ряду визначників [9, 17, 40]. Достовірність таксономічної належності підтверджено: по стафілінідах - к. б. н. А.А. Петренко (Київ), по турунах та більшості карапузиків i шкіроїдів - д.б.н. О. В. Пучковим (Київ); по більшості інших родин жуків О.О. Дрогваленко (Харків). Класифікація таксонів наведена за каталогами жуків Палеарктики [1-4].

Слід зазначити, що представлені нами дані в достатній мірі відображають рівень чисельності видів та особливості їх екологічної характеристики (особливо домінантів та субдомінантів), але в ході подальших досліджень, можливі деякі зміни та доповнення таксономічного складу i кількісного співвідношення жуків, особливо щодо нечисленних і випадкових видів. 


\section{РЕЗУЛЬТАТИ ТА ОБГОВОРЕННЯ}

Загалом, серед некробіонтної колеоптерофауни зареєстровано 66 видів 314 родин (табл. 1). При цьому 44 види виявлено за власними зборами, а 22 наведено за літературними даними [24]. При цьому, реєстрація деяких видівнекробіонтів в Харківській області викликає сумніви, а їх знахідки потребують підтверджень. Наприклад, стафілін Dinothenarus fossor Scopoli, 1771* (Staphylinidae) в Україні зареєстрований тільки в Закарпатті [21], а шкіроїд Dermestes kaszabi* (Dermestidae) та вусач Vadonia bipunctata Fabricius, 1781* (Cerambycidae) [31, 32, 39] вказані виключно для півдня Степу, тобто знахідки їх в інших географічних зонах України також потребують перевірки. Крім того, в палеарктичних каталогах для України відсутні всі види жуків-пістряків (Cleridae), шкіроїди Attagenus unicolor, Dermestes olivieri, D. erichsoni, та D. murinus [1, 3], хоча дані щодо їх знахідок в Україні неодноразово наводились в літературі [7, $22,31,40]$.

Деякі знахідки виявились фауністично цікавими. Так, на основі реєстрації нами шкіроїда Attagenus brunneus можна вважати цей вид новим для фауни України. Він не був вказаний для України як в останньому каталозі Палеарктики [3], так і у всіх відомих працях, хоча наведений для сусідніх країн (Білорусь, Угорщина, Словакія та південь европейської частини Росії). Уточнено поширення карапузиків Gnathoncus disjunctus suturifer, Saprinus planiusculus та $S$. rugifer, вперше зареєстрованих на території Лісостепу України [24]. Раніше ці види були вказані тільки для степової зони [9]. Все, вище наведене, вказує як на недостатню вивченість деяких родин жуків на теренах України, так і свідчить про необхідність подальших досліджень жуківнекробіонтів.

Крім того, відзначено i значні коливання видового різноманіття в окремі роки, періоди сезону та в різних біотопах, що буде розглянуто в окремій статті. Це опосередковано може бути підтверджено і незначним рівнем фауністичної подібності (на рівні біля 0,30-0,40 за Жаккаром) некробіонтної колеоптерофауни в наших дослідженнях порівняно 3 колеоптерофауною різних трансформованих ценозів Харківської області [7].

Більш різноманітною та чисельною (всього зазначено 23 види) серед видів безпосередньо пов'язаних з трупами були представники 5-и родин. 3 них серед Dermestidae зазначено дев'ять, Silphidae вісім, Nitidulidae - п'ять видів. Leiodidae представлені двома, a Trogidae - одним видом. Майже половина видів цієї групи (10) зареєстровані як масові або звичайні Це шість видів мертвоїдів, по одному шкіроїдів, лейодід та нітідулід (табл. 1).

Серед хижих ентомофагів, що живляться комахами трупної фауни (ентомофагів) виявлено 30 видів 3 трьох родин. Домінували Histeridae (15) та Staphylinidae (12 видів), а Cleridae представлені трьома видами. До звичайних (домінантів серед цієї групи не виявлено) віднесено сім видів з родин стафілінід (4) та карапузиків (3 види). Таким чином, за кількістю видів, хижаки майже на чверть переважали типових некрофагів, але чисельно ці групи майже не відрізнялись одна від одної.

Серед представників випадкової групи трупів, поки що поодиноко зареєстровано 13 видів жуків з семи родин. При цьому треба відзначити, що деякі види, хоча і віднесені до групи випадкових, все ж можуть бути факультативно пов'язані 3 трупами.

Це хижі жуки-туруни, що знаходять їжу біля трупів або деякі шкіроїди роду Attagenus які живляться залишками шерсті чи пір'я трупів. Таксономічно, кількість представників цієї групи, при подальших обліках, безсумнівно може зростати, відповідно саме їх випадковості.

При розгляді екологічної характеристики некробіонтних жуків (особливо за біотопічною преференцією) треба відзначити, що в літературі не завжди присутні уточнені дані для багатьох видів (особливо стафілінід, шкіроїдів та карапузиків). 
Частіше наведено відомості їх місцеперебувань (гній, трупи тварин, різноманітні укриття, листяна підстилка, нори тварин, тощо) та трофічну спеціалізацію. При проведенні аналізу екологічних груп, ми враховували особливості зміни стацій домінантних видів в умовах тих чи інших географічних зон України, рівень їх чисельності в різних природних і трансформованих біотопах. В деякій мірі, представлена в статті видова екологічна характеристика, носить суб'єктивний характер і в окремих роботах інших дослідників, одні і ті ж види можуть бути віднесені до різних (але близьких) груп. Проте, в цілому вони відповідають, наведеним в нашій праці, екологічним преферендумам тих чи інших видів некробіонтних жуків.

\section{Видовий склад, чисельність та екологічна характеристика жуків-некробіонтів (Харківська область)}

\begin{tabular}{|c|c|c|c|c|c|}
\hline Таксономічна структура & $\begin{array}{c}\text { Рівень } \\
\text { чисель- } \\
\text { ності } \\
\text { (в } \\
\text { балах) } \\
\end{array}$ & $\begin{array}{c}\text { Біото- } \\
\text { пічна } \\
\text { характе- } \\
\text { ристика }\end{array}$ & $\begin{array}{c}\text { Гігро- } \\
\text { префе- } \\
\text { рендум }\end{array}$ & $\begin{array}{c}\text { Трофіч } \\
\text { на } \\
\text { спеціа- } \\
\text { лізація }\end{array}$ & $\begin{array}{c}\text { Мікро- } \\
\text { стаціаль- } \\
\text { та належ- } \\
\text { ність }\end{array}$ \\
\hline \multicolumn{6}{|c|}{ Некробіонти що живляться трупами } \\
\hline $\begin{array}{l}\text { Silphidae - Мертвоїди } \\
\text { Necrodes littoralis Linneus, 1758* }\end{array}$ & 1 & пт & мгф & нзф & снкб \\
\hline Nicrophorus investigator Zetterstedt, 1834* & 1 & лс & мзф & нзф & снб \\
\hline Nicrophorus vespillo Linneus, 1758 & 3 & Пт & мзф & нзф & снб \\
\hline Nicrophorus vespilloides Herbst, 1783 & 2 & лс & мгф & нзф & снб \\
\hline Oiceptoma thoracica Linneus, 1758 & 2 & лс & мзф & н3ф & снб \\
\hline Silpha obscura Linnaeus, 1758 & 3 & Пт & мзф & плф & стб \\
\hline Thanatophilus rugosus Linnaeus, 1758 & 2 & Пт & мзф & нзф & снб \\
\hline Th. sinuatus Fabricius, 1758 & 2 & Пт & мзф & н3ф & снб \\
\hline $\begin{array}{l}\text { Leiodidae - Лейодіди } \\
\text { Catops sp.* }\end{array}$ & 1 & лс & мзф & нсф & снб \\
\hline Sciodrepoides sp. & 2 & Пт & мзф & Hсф & стб \\
\hline $\begin{array}{l}\text { Trogidae - Трокси } \\
\text { Trox hispidus Pontoppidan, } 1763\end{array}$ & 2 & лч & мкф & нсф & снб \\
\hline $\begin{array}{l}\text { Dermestidae - Шкіроїди } \\
\text { Dermestes erichsoni Ganglbauer, 1904*\# }\end{array}$ & 1 & лч & мкф & нсф & снб \\
\hline D. frischi Kugelann, 1792* & 1 & $\mathrm{cT}$ & мкф & Hсф & снб \\
\hline D. laniarius Illiger, 1801 & 2 & Пт & мзф & Hсф & стб \\
\hline D. lardarius Linnaeus, 1758 & 1 & $\mathrm{CH}$ & мзф & Hcф & сHT \\
\hline D. murinus Linnaeus, 1758 & 1 & лс & мзф & Hсф & снб \\
\hline D. olivieri Lepesme, $1939 *$ & 1 & лс & мзф & Hсф & стб \\
\hline D. undulatus Brahm, 1790 & 1 & лч & мкф & Hсф & снб \\
\hline $\begin{array}{l}\text { Nitidulidae - Нітідуліди (блищанки) } \\
\text { Epurea melanocephala Marsham, } 1802\end{array}$ & 1 & Пт & мзф & сфг & стб \\
\hline Nitidula flavomaculata Rossi, 1790* & 1 & ПТ & мзф & Hсф & снб \\
\hline N. rufipes Linnaeus, $1758^{*}$ & 1 & Пт & мзф & Hсф & снб \\
\hline Omosita colon Linnaeus, 1758 & 2 & Пт & мзф & сфг & стб \\
\hline O. discoides Fabricius, 1775 & 1 & лч & мзф & сфг & стб \\
\hline \multicolumn{6}{|c|}{ Нектобіонти-ентомофаги } \\
\hline Staphylinidae - Стафілініди & 1 & Пт & мзф & उфг & снкб \\
\hline
\end{tabular}




\begin{tabular}{|c|c|c|c|c|c|}
\hline Creophilus maxillosus Linnaeus, 1758 & & & & & \\
\hline Ontholestes murinus Linnaeus, 1758 & 2 & Пт & мзф & зфг & скнб \\
\hline Oxytelus fulvipes Erichson, 1839 & 1 & лс & мгф & зфф & сгб \\
\hline Philonthus addentus Sharp, 1867* & 1 & лс & м3ф & зфг & снкб \\
\hline Ph. carbonarius Gravenhorst, 1802 & 2 & лс & мгф & зфг & стб \\
\hline Ph. decorus Gravenhorst, 1802* & 1 & лс & мГф & зфг & снкб \\
\hline Ph. nitidus Fabricius 1787 & 1 & лс & мгф & зфг & стб \\
\hline Platydracus stercorarius Olivier, 1795 & 1 & Пт & мзф & зфг & снкб \\
\hline Rugilus rufipes Germar, 1836 & 2 & лс & м3ф & зфг & сгб \\
\hline Staphylinus caesareus Cederhjem 1798 & 2 & лс & мгф & зфг & снкб \\
\hline Dinothenarus pubescens DeGeer, 1774* & 1 & лч & мзф & зфг & снкб \\
\hline Tachinus humeralis Gravenhorst, 1802 & 1 & лс & мГф & зфг & стб \\
\hline $\begin{array}{l}\text { Histeridae - Карапузики } \\
\text { Atholus duodecimstriatus Gyllenhal, } 1808\end{array}$ & 1 & ПТ & мзф & зфг & скб \\
\hline $\begin{array}{l}\text { Gnathoncus disjunctus suturifer L.Scriba, } \\
\text { 1790\# }\end{array}$ & 1 & $\mathrm{cT}$ & мкф & зфг & сбб \\
\hline Hypocacculus rufipes Kugelan, 1792 & 1 & лч & мгф & зфг & снкб \\
\hline H. quadrinotatus L. Scriba, 1790 & 1 & Лч & мзф & зфг & скб \\
\hline H. quadrimaculatus Linnaeus, 1758 & 1 & Лч & м3ф & зфг & скб \\
\hline Margarinotus bipustulatus Schrank, 1781 & 1 & Лч & мкф & зфг & снкб \\
\hline M. brunneus Fabricius, 1798* & 1 & ПТ & мзф & зфг & снкб \\
\hline M. carbonarius Hoffmann, 1803* & 1 & лч & мзф & зфг & скб \\
\hline M. purpurascens Herbst, 1792 & 2 & Пт & м3ф & зфг & снкб \\
\hline M. ventralis Marseul, 1854* & 2 & лс & мзф & зфг & снкб \\
\hline Saprinus aeneus Fabricius, $1775^{*}$ & 1 & ПТ & мзф & зфг & снкб \\
\hline S. planiusculus Motschulsky, $1849^{* \#}$ & 1 & $\mathrm{cT}$ & мкф & зфг & снкб \\
\hline S. rugifer Paykull, 1809*\# & 1 & лс & мкф & зфг & сбб \\
\hline S. semistriatus L. Scriba, 1790* & 2 & Пт & мзф & зфг & снб \\
\hline S. tenuistrius Marseul, $1855^{*}$ & 1 & $\mathrm{cT}$ & мкф & зфг & снб \\
\hline $\begin{array}{l}\text { Cleridae - Пістряки } \\
\text { Necrobia ruficollis Fabricius, } 1775^{*}\end{array}$ & 1 & лс & мкф & нзф & снб \\
\hline N. rufipes DeGeer, 1775 & 1 & лс & мкф & н3ф & снб \\
\hline N. violacea Linnaeus, 1758 & 1 & лс & мкф & зфг & снб \\
\hline Випадкові види жу & Ha & біл/s & пів & & \\
\hline $\begin{array}{l}\text { Carabidae - Туруни } \\
\text { Calathus ambiguus Paykull, } 1790\end{array}$ & 1 & Пт & м3ф & зфг & стб \\
\hline Pterostichus melanarius Illiger, 1798 & 1 & Пт & мзф & зфг & стб \\
\hline Stomis pumicatus Panzer, 1795 & 1 & лс & мзф & зфг & стб \\
\hline $\begin{array}{l}\text { Нуdrophilidae - Водолюби } \\
\text { Cercyon haemorrhoidalis Fabricius } 1775^{*}\end{array}$ & 1 & лч & мгф & скф & скб \\
\hline $\begin{array}{l}\text { Dermestidae - Шкіроїди } \\
\text { Attagenus unicolor Brahm, 1790\# }\end{array}$ & 1 & лч & мкф & скф & сбб \\
\hline A. brunneus Faldermann, 1835 & 1 & $\mathrm{CH}$ & мкф & скф & стб \\
\hline $\begin{array}{l}\text { Coccinellidae - Сонечки } \\
\text { Adalia bipunctata Linnaeus, } 1758\end{array}$ & 1 & лс & мзф & зфг & днб \\
\hline $\begin{array}{l}\text { Scarabaeidae - Пластинчастовусі } \\
\text { Onthophagus coenobita Herbst, } 1783\end{array}$ & 1 & Пт & мзф & сфг & скб \\
\hline O. ovatus Linnaeus, 1758 & 1 & Пт & м3ф & сфг & скб \\
\hline Aphodius fumetarius Linnaeus, 1758 & 1 & лс & мзф & сфг & скб \\
\hline A. distinctus O. Müller, 1776 & 1 & лс & мзф & сфг & скб \\
\hline
\end{tabular}




\begin{tabular}{|l|c|c|c|c|c|}
\hline $\begin{array}{l}\text { Elateridae - Ковалики } \\
\text { Agrypnus murinus Linnaeus, 1758 }\end{array}$ & 1 & лс & мзф & сзф & схб \\
\hline $\begin{array}{l}\text { Chrysomelidae - Листоїди } \\
\text { Luperus anthopoda Schrank, 1781* }\end{array}$ & 1 & лс & мзф & ффг & днб \\
\hline
\end{tabular}

ПРИМІТКИ: чисельність: 3 - масовий (домінант); 2 - звичайний (субдомінант) 1 - поодинокий (рідкісний); біотопічна характеристика: пт - політопний; лс - лісовий; лч - лучний; ст - степовий; сн - синантроп; гігропреферендум: мзф мезофіл; мгф - мезогігрофіл; мкф - мезоксерофіл; трофічна спеціалізація: зфг - зоофаг; нзф - некрозоофаг; нсф некросапрофаг; сфг - сапрофаг; сзф - сапрозоофаг; скф-сапрокератофаг; плф - поліфаг; ффг - фітофаг; мікростаціальна (ярусна) належність: стб - стратобіонт; снб - стратонекробіонт скнб - стратокопронекробіонт; сбнб стратонекроботробіонт; скб - стратокопробіонт; снб - стратонекробіонт; сбб - стратоботробіонт; схб - стратохортобіонт; днб - дендробіонт; * - вид наведено за літературними даними [22]; \# - вид вперше вказаний для України або іії Лісостепової зони.

Під час досліджень за біотопічнною приналежністю всього виділено чотири основні екологічні групи: політопна, лугова, лісова та степова (табл. 1, рис. 1). Політопна група представлена 23 видами (близько 30\% всієї колеоптерофауни) 3 яких біля 10 зареєстровані як масові або звичайні. За рівнем чисельності, політопні види сягали майже третини зареєстрованих на трупах жуків. Серед видів, що живились різними частинами трупів відзначено 11, а ентомофагів - вісім політопних видів, з яких майже половина виявились фоновими. Лісова група як за кількістю видів (25), так і чисельністю не поступалась політопній.
Серед жуків, безпосередньо пов'язаних 3 трупами, виявлено шість, а серед хижаків - 13 лісових видів, серед яких загалом біля третини зареєстровані як фонові. Представники лучного комплексу за кількістю видів майже в два рази поступались попереднім біотопічним групам. За чисельністю ця різниця була ще більшою. Всього виявлено 12 видів 3 яких тільки Trox hispidus зареєстрований як субдомінант, а інші зустрічались поодиноко. До степових віднесено чотири види (головним чином окремі карапузики) чисельність яких завжди була низькою. Два види шкіроїдів відзначені як синантропи (табл. 1, рис. 1).

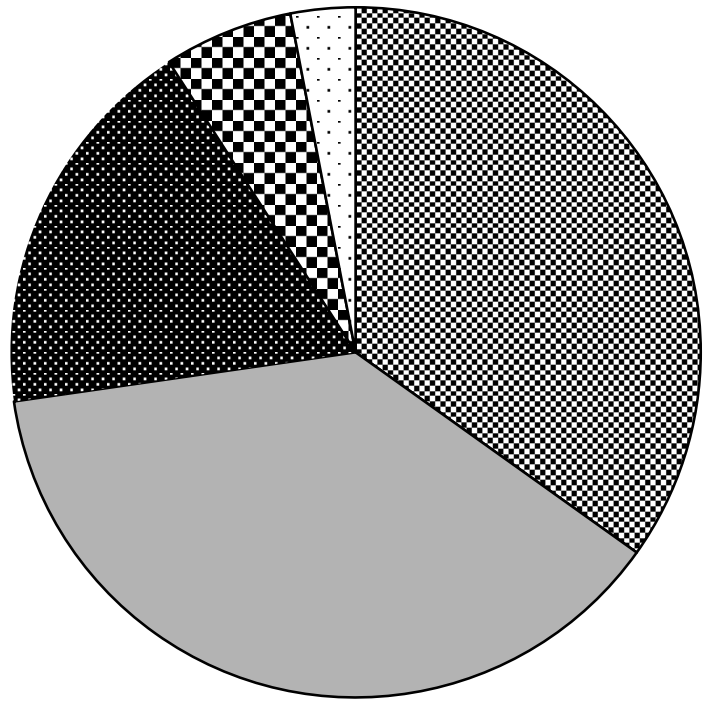

욕топні, 23 види, 34,8\%

$\square$ лісові, 25 видів, 37,9\%

лучні, 12 видів, 18,2\%

由 степові, 4 види, $6,1 \%$

๒ синантропи, 2 види, 3,0\%

Puc. 1. Розподіл та співвідношення видів некробіонтних жуків за біотопічною преференцією.

За гігропреферендумом еудомінантною групою були мезофіли (табл. 1, рис. 2). Серед них виявлено 45 видів, 3 яких 13 зареєстровані як домінанти та субдомінанти. Мезогігрофіли (головним чином стафілініди) представлені 10 видами, серед яких три виявились субдомінантами. До мезоксерофілів віднесено 12 видів, головним чином з родин шкіроїдів та деяких карапузиків (в основному роду Saprinus). Всі ці дві перехідні групи відзначені в незначній кількості. 


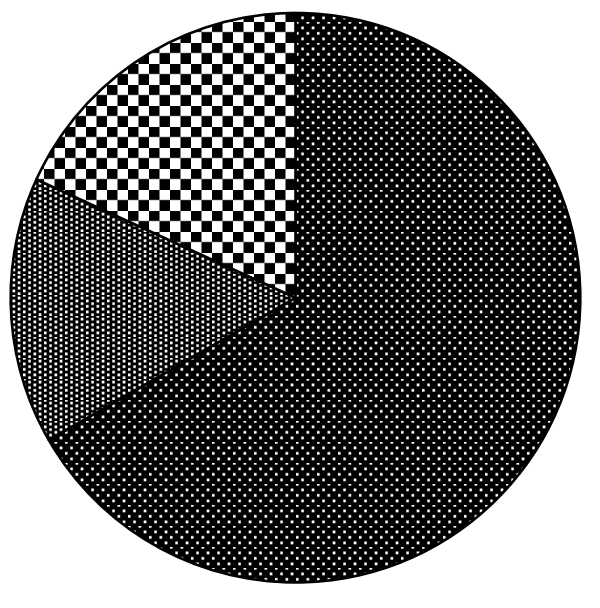

мезофіли, 44 види, 66,6\%

用 мезогігрофіли, 10 видів, $15,2 \%$

口 мезоксерофіли 12 видів, $18,2 \%$

Puc. 2. Розподіл та співвідношення видів некробіонтних жуків за гігропреферендумом.

Трофічна спеціалізація жуківнекробіонтів вивчена краще за інші екологічні особливості $[6,9,27,28,38,40]$. Основними групами на трупах $\epsilon$ некрозоофаги, зоофаги, некросапрофаги та сапрофаги широкого спектру (табл. 1, рис. 3). Інші групи представлені поодинокими видами. Таксономічно, домінантами

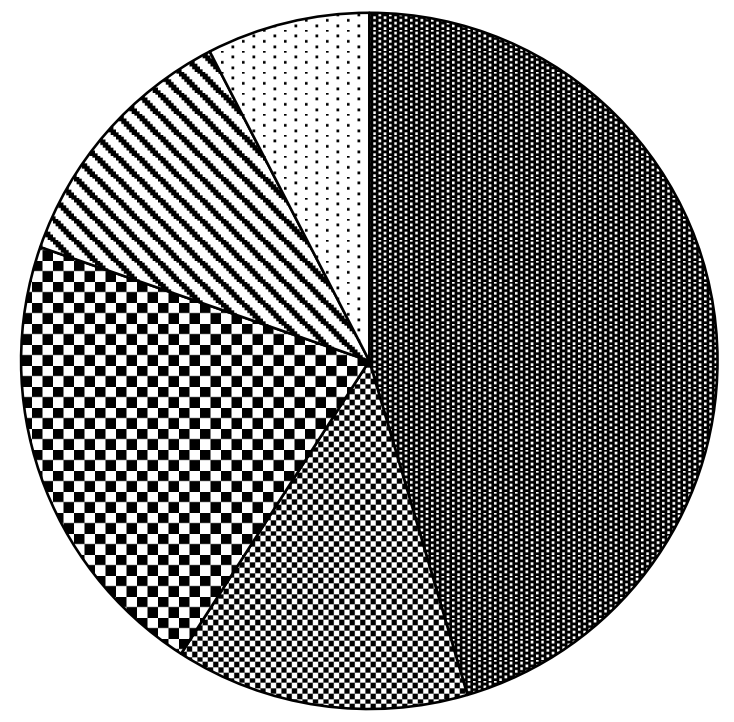

виявились зоофаги, серед яких зареєстровано майже половина всієї колеоптерофауни трупів (30 видів, 3 яких сім зареєстровані як звичайні). Головними представниками були стафілініди та карапузики, менше пістряки та деякі туруни.

进 зоофаги, 30 видів, 45,5\%

园 некрозоофаги, 9 видів, 13,6\%

некросапрофаги, 14 видів, $21,2 \%$

$\mathbf{\Delta}$ сапрофаги, 8 видів, 12,1\%

$\Xi$ інші трофічні групи, 5 видів, $7,5 \%$

Puc. 3. Розподіл та співвідношення видів некробіонтних жуків за трофічною спеціалізацією.

Біля чверті видів зазначені як некросапрофаги (14), що також розвиваються за рахунок трупів але можуть живитись i іншими органічними залишками (шкіроїди, лейодіди, трокси). Більшість їх зустрічались поодиноко і тільки три види зазначені як субдомінанти (табл. 1). До групи некрозоофагів віднесено майже 10 видів, які облігатно розвиваються на трупах, але в деяких випадках вони зареєстровані як ентомофаги (табл. 1, рис. 3). Чисельно, вони також переважали, головним чином 
за рахунок шістьох видів-домінантів та субдомінантів (в першу чергу мертвоїдів). Досить багатою таксономічно (8 видів) виявилась група типових сапрофагів, що живляться органікою, що розкладається тваринного та рослинного походження. Вони представлені пластинчастовусими, деякими водолюбами та нітідулідами, хоча чисельність їх (навідь сумарно) була досить низькою. Інші групи представлені поодинокими видами і відзначені як рідкісні. Це - сапрозоофаги (деякі ковалики), сапрокератофаги (окремі шкіроїди) та фітофаги (випадкові листоїди). Виключенням $€$ мертвоїд Silpha obscura, віднесений до поліфагів. Цей вид $\epsilon$ звичайним (іноді масовим) в багатьох ценозах, а спектр його живлення досить широкий: він відзначений

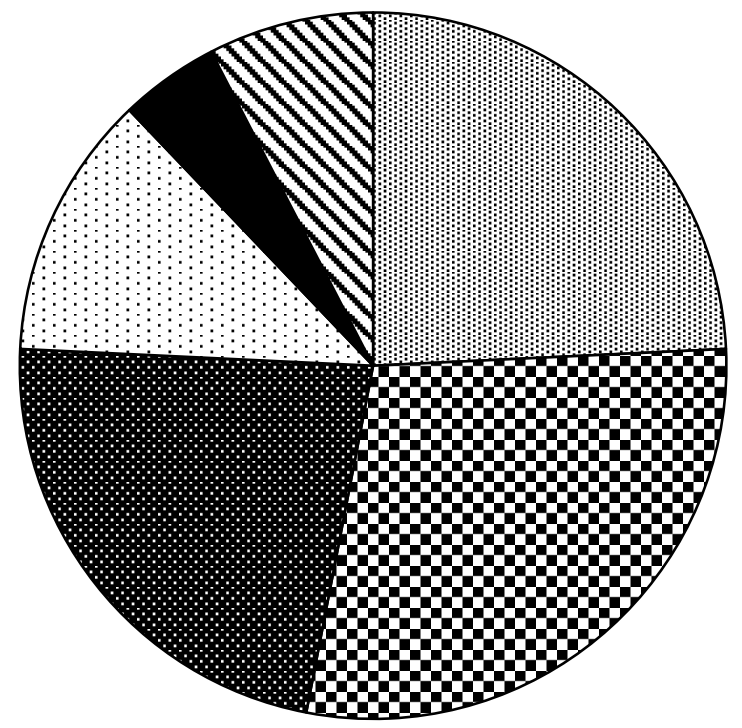

Puc. 4. Розподіл та співвідношення видів належністю.

До стратонекробіонтів віднесено 19 видів (з них шість звичайних), головним чином мертвоїдів, шкіроїдів, троксів та пістряків, менше - нідідулід та карапузиків. Серед стратобіонтів відзначено 16 видів, серед яких п'ять виявились звичайними (табл. 1, рис. 4). Основними були представники більшості родин жуків (деякі мертвоїди, шкіроїди, нітідуліди, стафілініди, та карапузики).

Стратокопронекробіонти представлені 15 видами (чотири відзначено як субдомінанти), 3 яких основними були стафілініди та карапузики. Чисельно, ці три як ентомофаг, некросапрофаг, а в деяких випадках - як фітофаг.

Дані щодо мікростаціального розподілу жуків-некрофагів також досить добре представлені в літературі [9-11, 18, 20, 21 27$30,37,38,40]$. Це результати обліків та зборів цих жуків в природі. На основі своїх та літературних даних нами було виділено вісім груп, серед яких основними виявились стратонекробіонти, що часто зустрічаються безпосередньо на трупах та в підстилці, стратобіонти - мешканці рослинної підстилки та верхніх шарів грунту, стратокопронекробіонти, що зустрічаються в рослинній підстилці, трупах та гної i стратокопробіонти, які зареєстровані як в підстилці, так і в гної тварин (табл. 1, рис. 4).

стратобіонти, 16 видів, 24,2\%

च стратонекробіонти, 19 видів, $28,8 \%$

욜 стратокопронекробіонти, 15 видів, $22,7 \%$

๑ стратокопробіонти, 8 видів, $12,1 \%$

- стратоботробіонти, 3 види, 4,5\%

बiнші групи, 5 видів, 7,7\%

некробіонтних жуків за мікростаціальною групи значно переважали на трупах, в порівнянні 3 іншими видами колеоптерокомплексу загалом. Серед стратокопробіонтів зареєстровано вісім видів, але серед них фонових елементів не відзначено. Інші мікростаціальні групи представлені стратоботробіонтами мешканцями підстилки та нір (три види карапузиків та шкіроїдів), стратогеобіонтами, що зустрічаються як в підстилці, так і у щілинах грунту (два види стафілінід), а також поодинокі (випадкові)

представники стратохортобіонтів та дендробіонтів (табл. 1, рис. 4). 


\section{ВИСНОВКИ}

В результаті проведених досліджень, серед некробіонтної колеоптерофауни, в Харківській області, зареєстровано 66 видів 3 14 родин. До жуків безпосередньо пов'язаних 3 трупами віднесено 23 види 3 5-и родин: Dermestidae (9), Silphidae (8), Nitidulidae (5 видів), Leiodidae (2) та Trogidae (один вид). Серед хижих ентомофагів виявлено 30 видів 3 трьох родин: Histeridae (15), Staphylinidae (12 видів) та Cleridae (3 види). Серед представників випадкової групи, поодиноко зареєстровано 13 видів жуків з семи родин. Шкіроїд Attagenus brunneus зареєстрований як новий для фауни України, а карапузики Gnathoncus disjunctus suturifer, Saprinus planiusculus та $S$. rugifer вперше відзначені на території Лісостепу України.

За біотопічною приналежністю домінували лісові (25) та політопні (23) види. Лучний комплекс включав 12 видів, до степових віднесено чотири, а до синантропів

\section{Лimepamypa}

1. Catalogue of Palearctic Coleoptera, 2004. Vol. 2. Hydrophiloidea - Histeroidea - Staphylinoidea. I. Löbl \& A. Smetana (Eds.). Apollo Books. 942 p.

2. Catalogue of Palearctic Coleoptera, 2006. Vol. 3. Scarabaeoidea - Scirtoidea - Dascilloidea Buprestoidea - Byrrhoidea. I. Löbl \& A. Smetana (Eds.). Apollo Books. 690 p.

3. Catalogue of Palearctic Coleoptera, 2007. Vol. 4. Elateroidea - Derodontoidea - Bostrichoidea Lymexyloidea - Cleroidea - Cucujoidea. I. Löbl \& A. Smetana (Eds.). Apollo Books. 935 p.

4. Catalogue of Palearctic Coleoptera, 2010. Vol. 6. Chrysomeloidea. I. Löbl \& A. Smetana (Eds.). Apollo Books. 924 p.

5. Chajka S. Yu. (2003) Sudebnaya entomologiya. Moskva: MAKS Press: 1-60 [in Russian]

6. Fabr Zh. A. (1993) Istrebiteli trupov. Instinkty i nravy nasekomyikh. M: Terra. 3 [in Russian]

7. Komaromi N. A., Nikolenko N. Yu., Putchkov A. V. (2018). Faunisticheskij sostav zhestkoryilyikh (Insecta: Coleoptera) herpetobiya urbotsenozov Harkova (Ukraina). Ukrainskiy entomologschniy zhurnal., $\quad 2 \quad$ (15): 21 3-21 https://doi.org/10.15421/281809 [in Russian].

8. Korzhova, T. A. Markina, T. Yu. Bachynska Ya. O. (2019). The species composition of insectnecrobionts in areas with different soil types in the vicinity of Kharkiv city (Ukraine). Biology and Valeology. 21: 97-103 [in Russian]

9. Kryzhanovskij O. L., Reykhardt A. N. (1976) Fauna SSSR. Zhestkokryilye, 5(4). Zhuki nadsemeistva
- два види. За гігропреферендумом домінували мезофіли (45 видів). Мезогігрофіли представлені 10, а мезоксерофіли - 12 видами. За трофічною спеціалізацією на трупах таксономічно домінували зоофаги (30), менше - некросапрофаги (14), некрозоофаги (10 видів) та сапрофаги широкого спектру (8 видів). Проте, чисельно переважали некросапрофаги та некрозоофаги. За мікростаціальною належністю виділено вісім груп, серед яких основними виявились стратонекробіонти (19), стратобіонти (16) та стратокопронекробіонти (15 видів). Чисельно ці три групи значно переважали на трупах, в порівнянні 3 іншими видами колеоптерокомплексу. Серед стратокопробіонтів зареєстровано вісім видів. Інші мікростаціальні групи представлені стратоботробіонтами (3 види), а також поодинокими стратогеобіонтами, стратохортобіонтами та дендробіонтами (по одному-двом видах кожна).

Histeroidea (Sphaeritidae, Histeridae, Synteliidae). Fauna of the USSR. Leningrad, Nauka. [in Russian]

10. Lyabzina S. N. (2011) Vidovoi sostav i struktura kompleksa chlenistonogikh-nekrobiontov Yuzhnoi Karelii. Uchenye zapiski Petrozavodskogo gosudarstvennogo universiteta. Ser.: Estestvennye i tehnicheskie nauki. 4 (117): 10-19 [in Russian]. Lyabzina S. N. (2019) Ekologiya kompleksa nekrofilnyikh bespozvonochnykh Severo-Zapada evropeyskoj chasti Rossii: avtoref. diss. ... dokt. biolog. nauk: 03.02.08: FGAOU VO «Rossiyskij universitet druzhby narodov» [in Russian].

12. Lyabzina S. N., Korosov A. V. (2013) Otsenka bioraznoobraziya zhestkokryilykh-nekrobiontov v Karelii. Printsipy ekologii. 2(4): 27-37 [in Russian].

13. Lyabzina S. N., Lavrukova O. S., Prichod'ko A. N., Azovskij A. I., Popov V. L. (2019) An insect complex of large animal carcasses and the peculiarities of their decomposition in northern European Russia. Entomological Review. 99: 473-484. https://doi.org/10.17116/sudmed201760518-22

14. Lyabzina, S. N. Prihod'ko A. N. (2016) Vozmozhnosti ispolzovaniya entomologicheskikh dannykh v sudebno-meditsinskoj ekspertize. Meditsinskaya ekspertiza i pravo. Moskva. 4: 38-41 [in Russian].

15. Lyabzina S. N., Uzenbaev S. D. (2013) Ekologiya zhukov-mertvoedov (Coleoptera, Silphidae) v Karelii. Uchenye zapiski Petrozavodskogo gosudarstvennogo universiteta. 2(131): 27-33 [in Russian]. 
16. Marchenko M. I., Kononenko V. I. (1991) Prakticheskoe rukovodstvo po sudebnoj entomologii. Harkov: 1-65 [in Russian]

17. Opredelitel nasekomyh Evropejskoj chasti SSSR. Zhestkokrylye, Veerokrylye (1965). Ed. G. BeiBienko. Leningrad: «Nauka».2 [in Russian].

18. Parhomenko O. V. (2001) Zhuki-mertvoidy (Coleoptera, Silphidae) fauny Ukrainy. Avtoref. diss. ...kand. boil. Nauk. Kyiv: 1-22 [in Ukrainian].

19. Parhomenko O. V. (2008) Zhyttevi tsikli rozvtku zhukiv-mertvoidiv (Coleoptera, Silphidae) fauny Ukraini. Naukoviy chasopis NPU MP Dragomanova. 20 Biologiya 2: 30-34 [in Ukrainian].

20. Parhomenko A. V. Brygadirenko V. V. (2003) Ekologicheskie vzaimosvyazi i raspredelenie mertvoedov (Coleoptera, Silphidae) poimennyih i arennyih ekosistem Samarskogo bora. Lesnoe stepnovedenie: 175-186 [in Russian].

21. Petrenko A. A. (1974) Korotkonadkrylye zhuki ili 32. staphilinidy (Coleoptera, Staphylinidae) Srednego Pridneprov'ya (ekologo-faunisticheskaya kharakteristika). Avtoref. diss. ...kand. biol. nauk. Kiev: 1-25 [in Russian].

22. Prokopenko A. A. (1986) Vozmozhnosti ispolzovaniya zoologicheskogo metoda $\mathrm{v}$ sudebnopochvovedcheskoj ekspertize. Kriminalistika i 34 sudebnaya ekspertiza. 33: 99-104 [in Russian].

23. Prokopenko A. A. (1994).-Entomologicheskiy analiz ( $(1 ; 1.4)$. Sudebno-pochvovedcheskaya ekspertiza: Metodicheskoe posobie dlya ekspertov, sledovateley i sudey. M.: VNIISE. 2: 55-67 [in Russian].

24. Prokopenko A. A. (2000). Sukcessionnye izmeneniya entomofauny trupa $\mathrm{i}$ ispolzovanie ih $\mathrm{v}$ sudebno-ekspertnoj praktike The Kharkov entomological society gazette. 8(2): 89-90 [in Russian].

25. Prokopenko A. A. (2002) Entomologicheskie issledovaniya $\mathrm{v}$ sudebno-biologicheskoj ekspertize zerna i zernoproduktov. Teoriya ta praktika sudovoyi 38 . ekspertizi i kriminalistiki. 2: 411-413 [in Russian].

26. Prokopenko O. O. (2003) Sezonni zmini vidovogo skladu nekroentomofauni. Teoriya ta praktika sudovoyi ekspertizi i kriminalistiki. 3: 362-367 [in Ukrainian]..

27. Pushkin S. V. (1999). Zhuki-nekrofagi v ekosistemah Stavropolskoj Vozvyishennosti. Semeistva (Silphidae, Dermestidae, Trogidae, Catopidae).
Stavropol: $\quad$ Izdatelstvo stavropolskogo gosudarstvennogo universiteta: 1-84 [in Russian].

28. Pushkin S. V., Kharchenko L. N. (1997). Pischevaya spetsializatsiya zhukov-nekrofagov. Fauna Stavropolya. Stavropol: SGU. 7: 60-64 [in Russian].

29. Pushkin S. V., Sigida S. I. (1998a) Osobennosti statsialnoj priurochennosti zhukov-mertvoedov (Coleoptera, Silphidae) v usloviyakh Stavropolya. Fauna Stavropolya: Sbornik nauchnyikh trudov. Stavropol: SGU. 8: 83-86 [in Russian].

30. Pushkin S. V., Sigida S. I. (1998b) K izucheniyu ekologii kozheedov (Coleoptera, Dermestidae) Stavropolya. Fauna Stavropolya: Sbornik nauchnyikh trudov. Stavropol: SGU. 8: 86-92 [in Russian].

31. Putchkov A. V. (1985) K ekologii kozheedov (Coleoptera, Dermestidae) ozimoj pshenitsy yuga stepnoy zony USSR. Vestnik zoologii. 1: 75-76 [in Russian].

Putchkov O. V. (2009) Zhuky-saprofagy (Insecta: Coleoptera) agrotsenoziv Ukrainy. BiologIya ta valeologiya, 11: 81-88 [in Ukrainian]..

Putchkov A. V. (2010) Zhuki-mertvoedy (Coleoptera, Silphidae) agrotsenozov Ukrainy. Ukrainskij entomologichnij zhurnal.. 1 (1): 71-79 [in Russian].

Putchkov O. V., Komaromi N. A. (2018). Zhukykarapuzyki (Coleoptera, Histeridae) urbotsenoziv Harkova (Ukraina). Biologiya ta Valeologiya. 20: 54-58. http://doi.org/10.5281/zenodo.2543636 [in Ukrainian].

35. Putchkov A. V., Petrenko A. A. (1986) Ekologicheskaya kharakteristika stafilinid (Coleoptera, Staphylinidae) pshenichnogo polya Stepi USSR. Vestn. zoologii. 2: 46-50 [in Russian].

36. Putchkov A. V., Shapran Yu. S. (1990). Karapuziki (Coleoptera, Histeridae) Lesostepi i Stepi Ukrainy. Vestnik zoologii. 1: 15-19 [in Russian].

37. Shapran Yu. P. (1991) Zhestkokrylye Histeridae (Coleoptera) fauny Ukrainy. Avtoref. ... kand. biol. nauk. Kiev: 1-23 [in Russian].

Tikhomirova A. L. Morphological and ecological features and phylogenesis of staphylinids (with a catalogue of USSR and adjacent territories). M.: Nauka, 1973. 191 p. [In Russian].

39. http://ukrbin.com/show_image.php?imageid=160 768 Vadonia bipunctata Fabricius, 1781.

Zhantiev R. D. (1976) Zhuki-kozheedy (Dermestidae) fauny SSSR. Moskva [in Russian].

\section{UDC 595.762}

\section{PECULIARITIES OF ECOLOGICAL STRUCTURE OF NECROBIONT BEETLES IN KHARKIV REGION (UKRAINE)}

\section{T.A. Korzhova, T.Yu. Markina}

Among the necrobiotic coleoptero fauna, 66 species of beetles from 14 families were registered (17 species were dominant or subdominant) in Kharkiv region (Ukraine). 23 species (10 of them are numerous) from 5 families as follows Dermestidae (9), Silphidae (8), Nitidulidae (5 species), Leiodidae (2) and Trogidae (one species) belong to the group of Saprotrophic (in a broad sense) organisms developing on the corpses. Among a group of predatory beetles, 30 species (seven are numerous) from such three families as Histeridae (15) and Staphylinidae (12 species) and Cleridae (3 species) were found: The most numerous were the species as follows: Nicrophorus vespillo, N. vespilloides, Oiceptoma thoracica, 
Silpha obscura, Tanathophilus rugosus, T. sinuatus (Silphidae), Dermestes laniarius (Dermestidae), Omosita colon (Nitidulidae), Sciodrepoides sp. (Leiodidae), Ontholestes murinus, Philonthus carbonarius, Rugilus rufipes, Staphilinus caesareus (Staphilinidae), Margarinotus purpurascens, M. ventralis, Saprinus semistriatus (Histeridae). Among the representatives of the random group, 13 species of beetles from seven families (some Carabidae, Hydrophilidae, Dermestidae, Coccinellidae, Scarabaeidae, Elateridae, Chrysomelidae) were registered. The skin beetle Attagenus brunneus (Dermestidae) has been registered as new to the fauna of Ukraine. Three species of clown beetles (Histeridae): Gnathoncus disjunctus suturifer, Saprinus planiusculus and S. rugifer were found at first time in the Forest-Steppe of Ukraine. According to biotope characteristics, forest (25) and polytopic (23) species dominated (15 species were dominants and subdominants). The meadow complex included 12 species, four species were classified as steppe ones and two species as synanthropes. According to the hygro-referendum, mesophilous (45 species) dominated (13 species were numerous). Mesohygrophilous are represented by 10 species, but mesoxerophilous - by 12 species only. In terms of trophic specialization, zoophagous (30 species) dominated taxonomically on the corpses. Necrosaprophagous (14), necrozoophagouse (10) and typical saprophagous ( 8 species) were registered too. However, necrosaprophagous and necrozoophagous (17 numerous species) are predominant. Eight groups were identified according to the microstations (microbiotops) type. The main ones were stratonecrobionts (19), stratobionts (16), stratocopronecrobionts (15 species). These three groups significantly predominated on corpses, in comparison with other species of cadaveric coleopterocomplex. Eight species were registered among stratocoprobionts. Other microstational groups are represented by stratobotrobionts ( 3 species) and single stratogeobionts, stratochortobionts and dendrobionts (1-2 species each).The data on species composition and number are given for each ecological group.

Key words: Coleoptera, necrobionts, biodiversity, corpses, species composition, number, ecological groups

Стаття надійшла 12. 11. 2020 р. Рекомендована до друку на засіданні редакційної колегії після рецензування 